is recognized, again in its proper place, in the chapter on Tertiary planation, etc. (p. 442). The two notices are paged in the Index under both Ballydeenlea and Killarney. The original short note has itself been amplified by additional matter, very kindly supplied, at my request, by Mr. Walsh and expressed in a form he approved.

\author{
Ballycastle, \\ Co. ANTRIM, \\ NORTHERN IRELAND. \\ 29th January, 1964.
}

\title{
PSEUDO-RIPPLE MARKS IN MIDDLE ORDOVICIAN LIMESTONE NEAR OTTAWA, CANADA
}

SIR,--Morphologically similar structures to the "unusual ripple marks" described by Shiells (1963) occur near Ottawa, but reveal additional features that indicate an entirely different mode of formation. They are located at a single exposure of a bed near the top of the Chaumont Formation, Black River Group (lower Caradocian age), on the Cobden-Eganville road, one mile south-west of Pine Valley, Bromley Township, 65 miles W.N.W. of Ottawa, Ontario.

The structures superficially resemble ripple marks, but are better termed pseudo-ripple marks, i.e. spurs with intervening grooves. Some 20 to 30 spurs, well exposed on both sides of the road, are traceable over 90 feet along their length. They are characteristically steep-sided and flat-topped, all having a similar elevation. They vary between 8 and 27 inches in width, but are most frequently between 8 to 12 and 20 to 27 inches. The larger, however, usually divide into two or more grooves along their length, beginning as shallow, troughs and deepening axially. The sides dip at angles exceeding 40 degrees, often approach vertical, and are sometimes undercut at the base. The basal width of the grooves averages 6 to 10 inches and rarely exceeds 15 inches. Their depth is normally 7 to 10 inches, thus giving a fairly symmetrical U-shaped profile in cross-section.

The structures are developed in the $10 \mathrm{in.}$ topmost bed of a fairly uniform $3 \mathrm{ft}$. unit. The whole sequence of strata is limestone with a few thin shaly partings. The bed in question is a poorly washed biopelsparite. Above are thin-bedded pelmicrites, the lower beds of which fill the grooves and pinch out over the spurs; higher ones continue across without variation in thickness. The spurs show internal stratification, allochems being aligned parallel to the bedding, which is truncated by the troughs.

The steep inclination and occasional undercutting of the spur sides, the abrupt truncation of internal stratification, and the flat-topped nature of the spurs indicate erosion of an, at least partially, lithified bed prior to the deposition of the overlying pelmicrites. No modern carbonates, however, are known to have become lithified without either subaerial exposure in the intertidal zone or burial to depths exceeding 150 metres (Jaanusson, 1961). All stratigraphic evidence suggests the latter to be impossible; thus, lithification seems to have occurred in the former environment, presumably under the conditions which give rise to modern beachrock (Russel, 1962). The spurs exposed show remarkable parallelism, with a constant direction, but without corrosion or discontinuity features. Thus, submarine erosion in a breaker-zone, caused by vigorous undertow scour and possibly rip-currents, is considered responsible for the structures.

Several types of spur-and-groove systems have been described in recent years from modern shallow-shelf, atoll and reef environments, particularly by Newell and associates and by Cloud. Some are shown to be erosional features, also with pronounced parallelism, and thought to be caused by undertow currents. The modern analogues have a great range of dimensions, but some of only slightly larger size than the Ordovician forms, are reported by Cloud 
(1959) from Saipan. These modern examples are restricted to a particular environment which the writer believes can be shown to exist in the Ordovician limestones under review.

The " unusual ripple marks" described by Shiells are essentially of the same dimensions as those reported here, except that the spurs are thinner and less flat-topped, whilst the grooves are wider. This, however, could merely be a reflection of a more advanced stage of erosion and spur slope retreat. Unfortunately the Carboniferous structures are developed in calcilutite with no internal stratification that could reveal truncation. Shiells believes the spurs to be developed as static ridges without any lateral translation or migration of particles, the pattern being developed and controlled by oscillation wave motion. Spur growth is considered to occur through the collection, cohesion and partial consolidation of calcilutite material. This mode of formation is not easily reconciled with observed processes of modern carbonate consolidation as reviewed by Jaanusson (op. cit. p. 231), who also suggests that the extensive lithification is theoretically impossible in shallow-water. Further, it is unlikely that the oscillation wave motion could exist for extended periods of time, thus the deposition of calcilutite must have been extremely rapid in the accumulation of spurs up to 9 inches in amplitude. Again, recent studies in rates of modern carbonate sedimentation do not support this, even allowing for concentration of material on to the spurs; thus Cloud (1962, p. 36) calculates a rate of $1 \mathrm{~mm}$. per year for pelletal aragonite muds on the Bahama Banks. It is therefore suggested that the Carboniferous structures may be better explained by the hypothesis presented for the origin of similar Ordovician forms.

Christopher R. Barnes.

\author{
Department of Geology, \\ UNIVERSITY OF OTTAWA, \\ OTTAWA 2, \\ ONTARIO, \\ CANADA.
}

February, 1964.

\title{
REFERENCES
}

Cloud, P. E., JR., 1959. Geology of Saipan, Mariana Islands; Part 4, Submarine topography and shoal water ecology. U. S. Geol. Surv. Prof. Paper, 280-K, 361-445.

1962. Environment of calcium carbonate deposition west of Andros Island, Bahamas. U. S. Geol. Surv. Prof. Paper, 350.

JaAnusson, V., 1961. Discontinuity surfaces in limestones. Geol. Inst. Univ. Upsala Bull., 40, 221-241,

Russel, R. J., 1962. Origin of beach rock. Ztschrft. für Geomorph. N. F. 6, 1-16.

Shiells, K. A. G., 1963. Some unusual ripple marks in Carboniferous Limestone near Spittal, North Northumberland. Geol. Mag., 100, 498-502.

\section{PSEUDO-RIPPLE MARKS: A REPLY}

SIR,- The suggested common origin for the ripple marks of Northumberland and the spur and groove features found near Ottawa cannot be upheld. The postulate that the Northumberland structures might represent a beachrock which was partially eroded before the deposition of the overlying shale is discounted on the following evidence :-

1. The ripple marks are built-up above the surface of an otherwise uniformly thick limestone bed and are not remnant ridges of erosion.

2. The ripple marks of unusual dimensions grade into marginal zones of normal proportions. 